\title{
Natural building stones of Mexico-Tenochtitlán: their use, weathering and rock properties at the Templo Mayor, Palace Heras Soto and the Metropolitan Cathedral
}

\author{
Wanja Wedekind · Joerg Ruedrich • \\ Siegfried Siegesmund
}

Received: 8 March 2011 / Accepted: 22 April 2011/Published online: 26 May 2011

(c) The Author(s) 2011. This article is published with open access at Springerlink.com

\begin{abstract}
In the Aztec period and in colonial times different natural stones originating in the Valley of Mexico were used for building construction. Stone weathering was investigated onsite at various historical buildings within the old quarter of Mexico City. In this study, different aspects of weathering and deterioration at three significant historical buildings will be presented, the Aztec excavation site Templo Mayor, the Metropolitan Cathedral, and the colonial palace of the dukes of Heras Soto. Petrophysical properties of the main building stones of these structures were investigated like density, porosity, pore radii distribution, water uptake rate and coefficient, thermal and hygric expansion, and the mechanical properties of uniaxial compressive strength. A relationship between single critical property values, according to anisotropy fabric characteristics, and specific weathering forms could be deduced.
\end{abstract}

Keywords Stone weathering - Mexico-DF .

Petrophysical properties · Isotropy-anisotropy $\cdot$ Critical values

\section{Introduction}

Because of its geological setting, volcanic rocks are the most prevalent rock types in the Valley of Mexico. Mexico City, formerly called Mexico-Tenochtitlán by the Aztecs, is located in the Valley of Mexico in the center of the Trans-Mexican Volcanic Belt. Located in the high plateaus

W. Wedekind $(\varangle) \cdot$ J. Ruedrich $\cdot$ S. Siegesmund

Geoscience Centre of the University Göttingen,

Goldschmidtstr.3, 37077 Göttingen, Germany

e-mail: wwedekind@gmx.de of south-central Mexico, it has a minimum altitude of 2,200 $\mathrm{m}$ above sea level. Mountains and volcanoes that attain elevations of over $5,000 \mathrm{~m}$ surround the once characteristic Lakeland area of the valley. Today only small remnants of the historical Lake Texaco are left, which once had dimensions of $72 \mathrm{~km}$ by $35 \mathrm{~km}$.

Human settlements in the Valley of Mexico have a very long history; initial traces of agriculture around the lake began about 7,000 years BCE (Niederberger 1979) and the first evidence of villages occur between 1,700 and 1,250 BCE, which developed the first identifiable cultures (Neiderberger 1996). Around 2,000 years later, the founding of the Aztec capital Tenochtitlán took place in 1325 . The city of Tenochtitlán was destroyed under the command of Hernan Cortes (1485-1557) in the summer of 1521. The once largest city (Sanders 2008) of the Americas had been razed to the ground and an estimated 240,000 Aztecs died (Hassig 1994) during the fall of their capital. The Aztec culture and the Spanish Conquistadors left behind a large stone building legacy. Within the $9 \mathrm{~km}^{2}$ area of the historical city center, around 1,500 historical buildings and 200 monuments are preserved and 80 museums are located. In 1987, the UNESCO declared the historical center of Mexico City a World Heritage Site. Today many campaigns for restoration and the rehabilitation of the historical center were done or are still in the planning stage.

Weathering and stone deterioration in this region is affected by four main factors: the extreme pollution of the metropolitan area, the semi-arid to subtropical climate, the specific hydrological situation, and the frequent seismic activity. In general, weathering and deterioration of building stones in Mexico City have been poorly investigated.

Different publications exist concerning the restoration of the Metropolitan Cathedral, but they mostly focus on 
structural surveys (Ortiz Lajous 1980; Tamez et al. 1997). Publications dealing with petrophysical investigations on the building materials are rare. For example, geotechnical investigations by Pirella and Ramírez (2001) were done on just one column of the cathedral.

Other investigations studied just one type of volcanic tuff variety, which is used on many historical facades in the city (Suárez Pareyón Aveleyra 2002). The influences of urban and industrial pollution on stone were discussed by Martínez and Martínez (1991) for three types of stone also investigated in this paper.

Five different types of the main building stones from the Valley of Mexico were investigated for mineralogical and petrophysical characterization. Altogether six large-scaled samples of the original historical and already weathered material from the Cathedral and the Templo Mayor as well as fresh building material from different local quarries were selected. The sample of the Cathedral was from the roof covering of the left tower and the samples of the Templo Mayor were fragments of historical floor plates.

\section{Methods}

The petrophysical properties analyzed in this investigation are density, porosity, pore radii distribution, water uptake rate and coefficient, thermal and hygric expansion as well as the mechanical properties of uniaxial compressive strength. For the last three parameters, the investigations were carried out in three different fabric directions, parallel $(Y)$ and perpendicular $(Z)$ to the foliation and as far as possible parallel to the lineation $(X)$.

The laboratory tests are complemented with field observations consisting of mapping and diagnostic measurements on the objects such as surface temperature, electrical conductivity and shore-hardness tests on the stone surfaces.

In order to acquire the matrix and bulk density as well as the porosity, hydrostatic weighing was carried out. Water uptake was determined by capillary suction in a closed cabinet while weighing. The water uptake coefficient ( $w$ value) describes how much water can be absorbed in a definite time according to the area of suction. The pore radii distribution was analyzed by using the mercury injection porosimetry (e.g., Brakel et al. 1981).

The hygric expansion is a property of some materials (e.g., clay minerals), which causes them to swell in contact with water. The present explanation is that this behavior is controlled by the amount of swelling clay minerals and the proportion of micropores present in the rock (see discussion in Weiss et al. 2004 or Ruedrich et al. 2005 and Ruedrich and Siegesmund in this issue). The hygric expansion of the stones was determined on cylindrical samples (diameter $40 \mathrm{~mm}$, length $50 \mathrm{~mm}$ ), which were preconditioned at $30 \%$ relative humidity and room temperature. Afterwards, the samples were completely immersed in distilled water. Thermal expansion was measured on cylindrical samples (diameter $15 \mathrm{~mm}$, length $50 \mathrm{~mm}$ ) by heating up to $90^{\circ} \mathrm{C}$ and cooling down to $20^{\circ} \mathrm{C}$ during five cycles to determine an eventually residual (irreversible) strain.

For the compressive strength tests, standard cylindrical specimens of $25.4 \mathrm{~mm}$ in diameter and $50 \mathrm{~mm}$ in length with co-planar end-faces were used. After grinding, all specimens were dried at $50^{\circ} \mathrm{C}$ until weight constancy was achieved. This weight is defined as the dry status of the specimens.

In the next step, one charge of the specimens was evacuated and saturated with water up to weight constancy, which defines the fully saturated sample condition $(100 \%$ water saturation). The compressive load was applied by a servo-hydraulic testing machine with a very stiff testing frame $\left(3,000 \mathrm{kN} / \mathrm{mm}^{2}\right)$ and a class 1 load range up to $300 \mathrm{kN}$. The load was applied to the end-faces of the specimen with a strain rate of $10-5 \mathrm{~s}^{-1}$ until failure. The maximum load is defined as the uniaxial compressive strength.

\section{Mapping and in situ investigations of the buildings}

\section{The Templo Mayor}

The Templo Mayor was one of the main temples of the Aztecs in their capital city of Tenochtitlán, which represents Mexico City today. The temple is located in the center of the historical town and was once the central part of the ceremonial center of Tenochtitlán. The Templo Mayor was originally a towering pyramid topped by two sanctuaries (Fig. 1a). The outline of the temple measuring approximately $100-80 \mathrm{~m}$ at its base dominated a sacred precinct. The construction was based on hundreds or even thousands of fence-post-sized supporting piles within the porous marshy terrain to stabilize the building (Sanders 2008). Construction of the first temple started around 1324. The sixth and last rebuild took place in 1487 (Parker 1995) (Fig. 1a). In 1521, the Spanish systematically destroyed the temple.

The first fragments of the temple were recovered at the end of the nineteenth century and the first half of the twentieth century. Systematic excavations took place from 1978 to 1982 by the demolition of 13 younger buildings. In 1980, the site was restored and treated with impregnation materials using silanes and hydrophobizantes (Franco 1987; Wacker and Meyer 1997). Since 1987, the site has been added to the UNESCO World Heritage List. 
Fig. 1 The investigated buildings within the historical center: $a$ location and model of the Templo Mayor, $b$ the palace of the dukes of Heras Soto and $c$ the Metropolitan Cathedral with the left tower under restoration

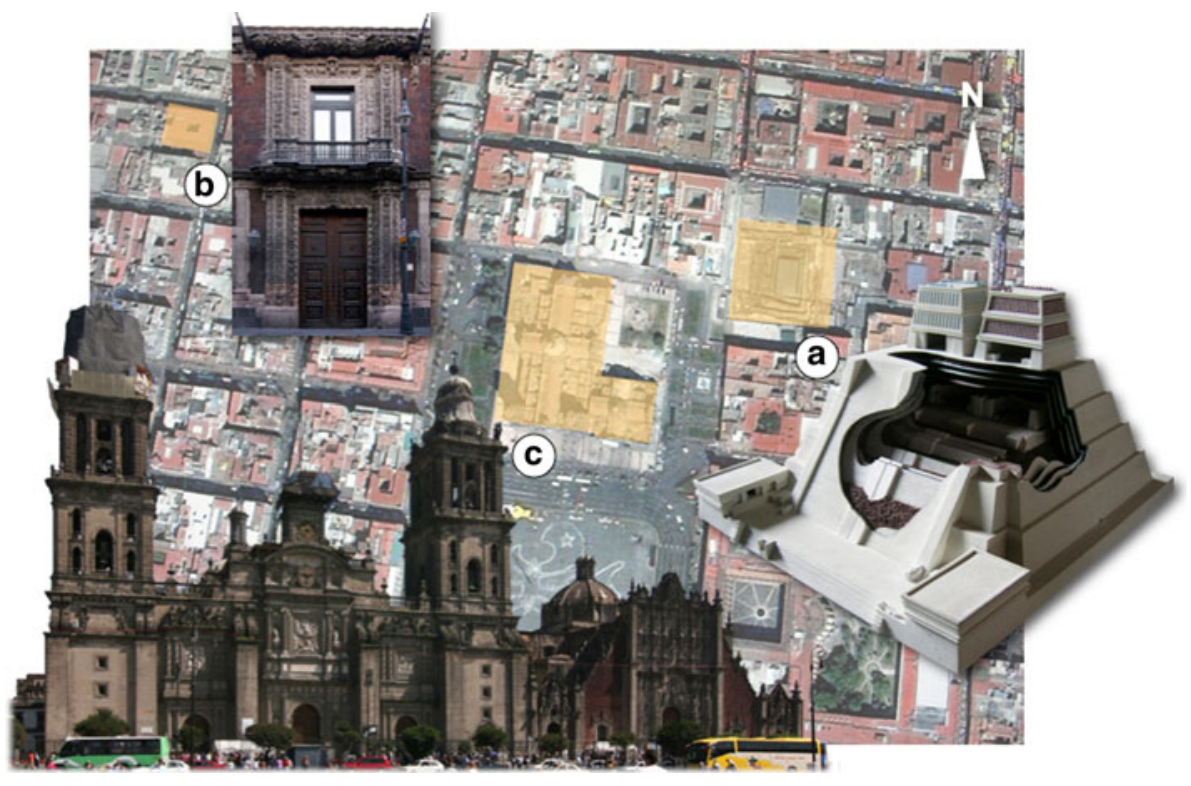

Stone, adobe, wood, and lime mortar were the main building materials used in Aztec architecture (López Luján et al. 2003). In the Templo Mayor, the main building stone is called "tezontle" (I), which in the Aztec language, Nuatle, is the appellation for an extrusive volcanic basaltic andesite scoria. These dominant building materials are followed by different other types of andesite, and rarely by basalts popularly known as "recinto" as well as limestones.

Weathering is mostly visible in the tezontle and a reddish basaltic hornblende andesite, in Nuatle known as tenayocátetl (II). This material was used as floor or facing plates or for platform structures.

While the most recognizable deterioration in the tezontle consists of fractures and cracks (Fig. 2a), the weathering feature observable in the tenayocátetl is a scaling parallel to the surface with a thickness of $2-5 \mathrm{~mm}$ (Fig. 2b). Both weathering forms are specific for each single type of stone. Especially in the case of the tenayocátetl, the damages are observable on plenty of plates in the platform. In this study, tezontle from a quarry in the state of Mexico, which is used for plenty of restoration works today and the tenayocátetl from the Templo Mayor has been investigated.

\section{Palace of the dukes of Heras Soto}

The Palace of the dukes of Heras Soto was built during the period, 1753-1760, and was the representative domicile of Adrián Ximénes de Alendral, a rich tradesman for silver (Fig. 1b). The name given to the palace-like residence was because of its aristocratic inhabitant in the nineteenth century (Demm 1991). The building in style and construction is a typical exponent of the baroque colonial palace in Mexico City. The residence is nearly 40 by $40 \mathrm{~m}$ in size and is a two-storied building with a center court and arcaded sidewalk. The domicile is located at a distance of two blocks northwest from the cathedral. A first comprehensive restoration took place in 1978. In 1931, the building was declared a historic monument and is part of the UNESCO World Heritage List of Mexico-DF. The bare brickwork of the typical palaces and houses is made of bricks and adobe, while different building stones cover the façades. The same construction is found in the case of the palace, Heras Soto.

Beside tezontle, recinto, and tenayocátetl, the most dominant building stone is "cantera" Gris de los Remedios (III). The ornamental sculpture of the facade is made from these devitrified tuffs (Fig. 1b).

Weathering can be recognized in the basement area of the building, especially where the sunlit façades are affected by deterioration (Fig. 3a). In the case of this colonial building, the material of the tenayocátetl variety is used as building blocks, mostly horizontal to the flowing structure, which means the bedding or flow structure is observable.

The tenayocátetl variety shows extreme back-weathering of layers and partial detachment by fragmentation. Ashlars are used like plates, which means perpendicular to the flow structure and also scaling is observable. Consequently, the outline single ashlars show rounding (Fig. 3a, d). Weathering also takes place on the tuff stone connected to the basement area. Two weathering forms can be distinguished: scaling with a thickness up to $1 \mathrm{~cm}$ parallel to the surface and rounding by splitting and sanding (Fig. 3c). In general, the Gris de los Remedios shows a high resistance to weathering. Only in building parts exposed to wetdry conditions, like the foundations or balconies, is backweathering able to be detected. 

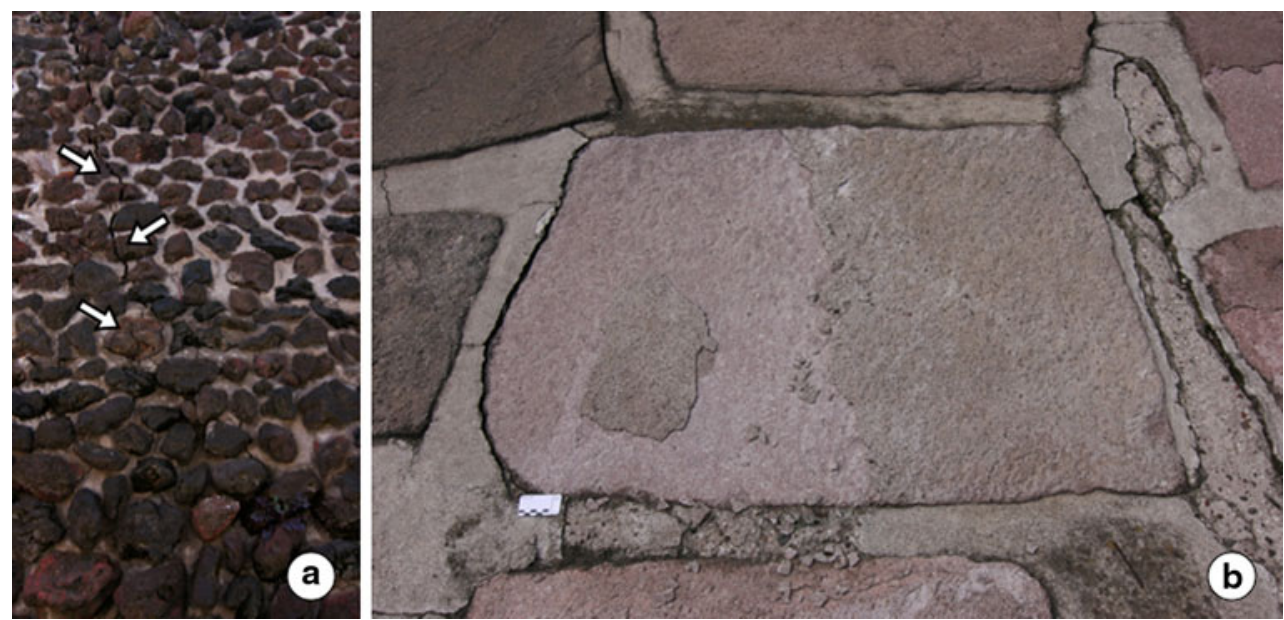

Fig. 2 a Structural cracks observable in the tezontle (arrows) and b scaling of tenayocátetl plates parallel to the surface

Fig. 3 a Weathered and replaced building stones at the ground level, b Mapping area, c lithographic mapping, d Mapping of damages
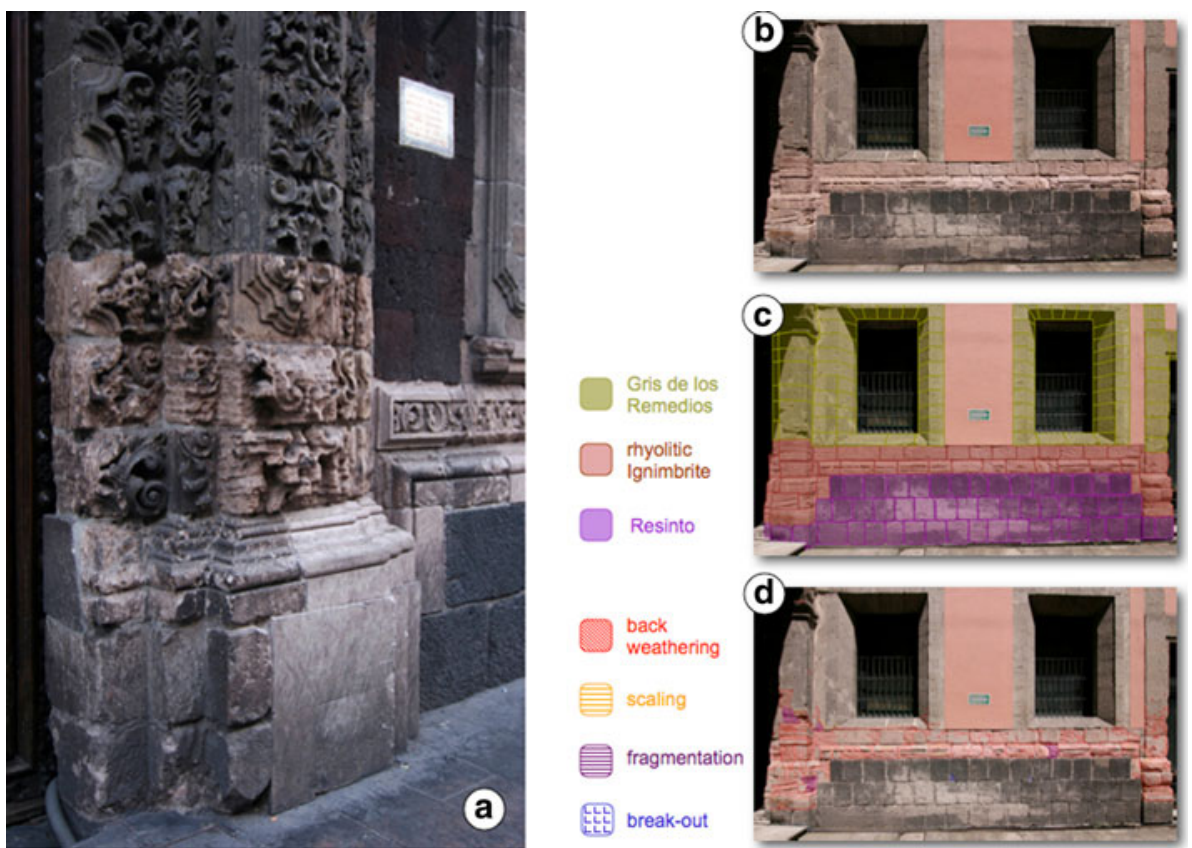

The Metropolitan Cathedral

The Metropolitan Cathedral of Mexico City was constructed from 1573 to 1813 on the former Aztec ceremonial center. The cathedral is the largest and oldest in the Americas (Fig. 1c). The cathedral facades are oriented to the south and are approximately $54.5 \mathrm{~m}$ wide and $110 \mathrm{~m}$ long. The two bell towers were constructed in the latter half of the eighteenth century. The building combined different architectural styles like the Baroque, Neo-Renaissance, and Neo-Classic.

Seismic activity and ground subsidence in the area has affected the cathedral's construction. Besides the structural problems, weathering takes place especially on building parts exposed to wet-dry conditions. Restorations have been carried out throughout the entire history of this large building. After the restoration of the cupola in the last several years, the bell towers are now currently undergoing restoration.

Because the cathedral was constructed over a period of more than two centuries, not only is its design a mixture of different architectural styles, but also all the various building stones used originating from the Valley of Mexico can be seen on different parts of the building. The main building stones used consist of tezontle, tuff stone, and andesite (Pirella and Ramírez 2001).

The main building stone used for the main facade and the two towers is a gray to green colored pyroxene andesitic tuff (IV). Present-day restoration work uses a similar variety originating from the Chiluca quarries (V). In 
this study, we focus on these building materials because of their significant weathering features and because of their importance as historical building material. The pyroxene andesite of the Metropolitan Cathedral shows a typical weathering form starting with crust formation, and then scaling due to flaking and rounding (Fig. 4).

During the process of weathering, the first centimeter of the stone material is especially affected. Thus, the pore radii distribution, porosity, capillary water uptake, and hardness change. Tests conducted in the laboratory with this weathered material clearly demonstrated this process. After the moistening of a truncated stone sample, the water penetrates and remains in the weathered zone only (Fig. 5a). Here the pore size contribution changes for the benefit of a higher amount of capillary active pores from 27 to $76 \%$ in comparison to the unweathered material (Fig. 5I-III). Capillary active pores are defined as those having a cross-sectional dimension ranging from 0.1 to $>100 \mu \mathrm{m}$ (Klopfer 1985). Porosity increases from 10 to $13 \%$ (Fig. 5I-III), whereas the surface hardness measured with a durometer DO (ASTM D 2240), decreases down to $70 \%$ in comparison to the intact material.

Today the outlines and sharp edges of cut stones often are back-weathered. These weathering processes take place especially in the pedestal area (Fig. 5b) or in building parts, which are exposed to rain and down flowing water.

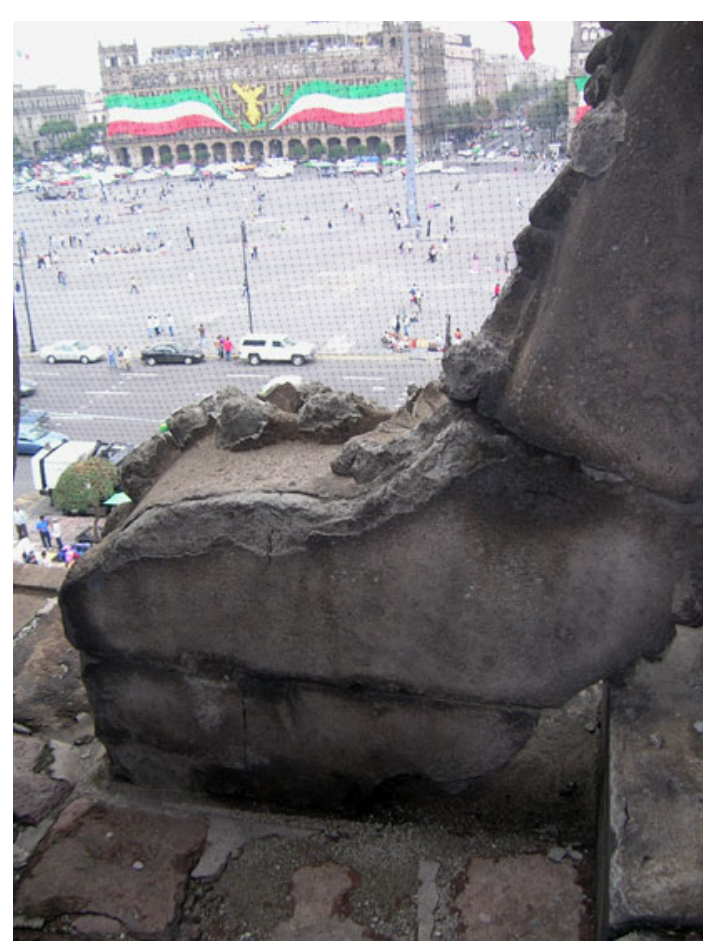

Fig. 4 Crust formation, scaling and rounding of a sculpture at the Metropolitan Cathedral

\section{Rock fabrics and petrophysical properties}

Tezontle basalt

Of the vesicular Tezontle basalt (I) fresh material of a quarry nearby Mexico City was investigated. Macroscopically it shows a typical cellular fabric. The voids are predominantly $8 \mathrm{~mm}$ in diameter. Locally, partially melted rock fragments from older volcanic rocks are incorporated. These fragments show irregular shapes with a red colored rim, which can be traced back to iron oxide minerals.

Microscopically the cell walls of the cellular rock fabric show a cryptocrystalline fabric with acicular plagioclase crystals. Only isolated small pyroxene and amphibole crystals as well as hematite impregnations occur (Fig. 6I). X-ray fluorescence analyses after Acevedo-Dávila et al. 2007. The Tezontle basalt geochemically contains approximately $60 \% \quad \mathrm{SiO}_{2}, 12 \% \quad \mathrm{Al}_{2} \mathrm{O}_{3}, 8 \% \mathrm{MgO}, 5 \%$ $\mathrm{Fe} 2 \mathrm{O}_{3}, 4 \% \mathrm{CaO}$ and $3 \% \mathrm{Na}_{2} \mathrm{O}$.

The material is permeated by fractures and small cracks. Its porosity in non-weathered conditions ranges from 35 to $66 \%$ with an average value of 52 vol. $\%$. This strong variation of the porosity can be traced back to its heterogeneous cellular structure. Due to the high porosity the bulk density with a value of $1.4 \mathrm{~g} / \mathrm{cm}^{3}$ is very low. The particle or matrix density reaches a value of about $2.71 \mathrm{~g} / \mathrm{cm}^{3}$. Possibly mafic minerals like pyroxene and amphibole possibly cause this relatively high value. The average $w$ value only reaches $0.40 \mathrm{~kg} \mathrm{~m}^{-2} \mathrm{~h}^{-1 / 2}$. Active capillary pores amount to $76.2 \%$ of the pore radii distribution by a considerable outbalance of larger capillary pores $(>10 \mu \mathrm{m}=43.7 \%)$ and macro pores (Table 1). Furthermore, the basalt exhibits no measurable hygric swelling but with $7.010^{-6} \mathrm{~K}^{-1}$ a relatively high thermal dilatation coefficient (Table 3). A residual strain after five cycles could not be detected.

Under dry conditions, the compressive strength ranges from 12 to $32 \mathrm{~N} / \mathrm{mm}^{2}$. The highest values are reached in $Z$ direction averaged with $27 \mathrm{~N} / \mathrm{mm}^{2}$. The lowest values were measured in $Y$ direction averaged with around $21 \mathrm{~N} /$ $\mathrm{mm}^{2}$. The anisotropy amounts nearly $21 \%$ (Table 4$)$. The modulus of elasticity ranges from 3.57 to $8.34 \mathrm{kN} / \mathrm{mm}^{2}$ with an anisotropic behavior of around 13\%. The uniaxial compressive strength is with $23.8 \mathrm{~N} / \mathrm{mm}^{2}$ very low. Under dry sample conditions, the strength varies between 21.33 and $26.90 \mathrm{~N} / \mathrm{mm}^{2}$. In contrast, the uniaxial compressive strength values of the water-saturated specimens are $3 \%$ higher and range between 27.76 and 22.31 (Table 4). This is caused by the rock heterogeneity, and thus the rock strength does not depend on the water content. The Young's modulus of the Tezontle rock is around $5.7 \mathrm{kN} /$ $\mathrm{mm}^{2}$ (Table 4). 

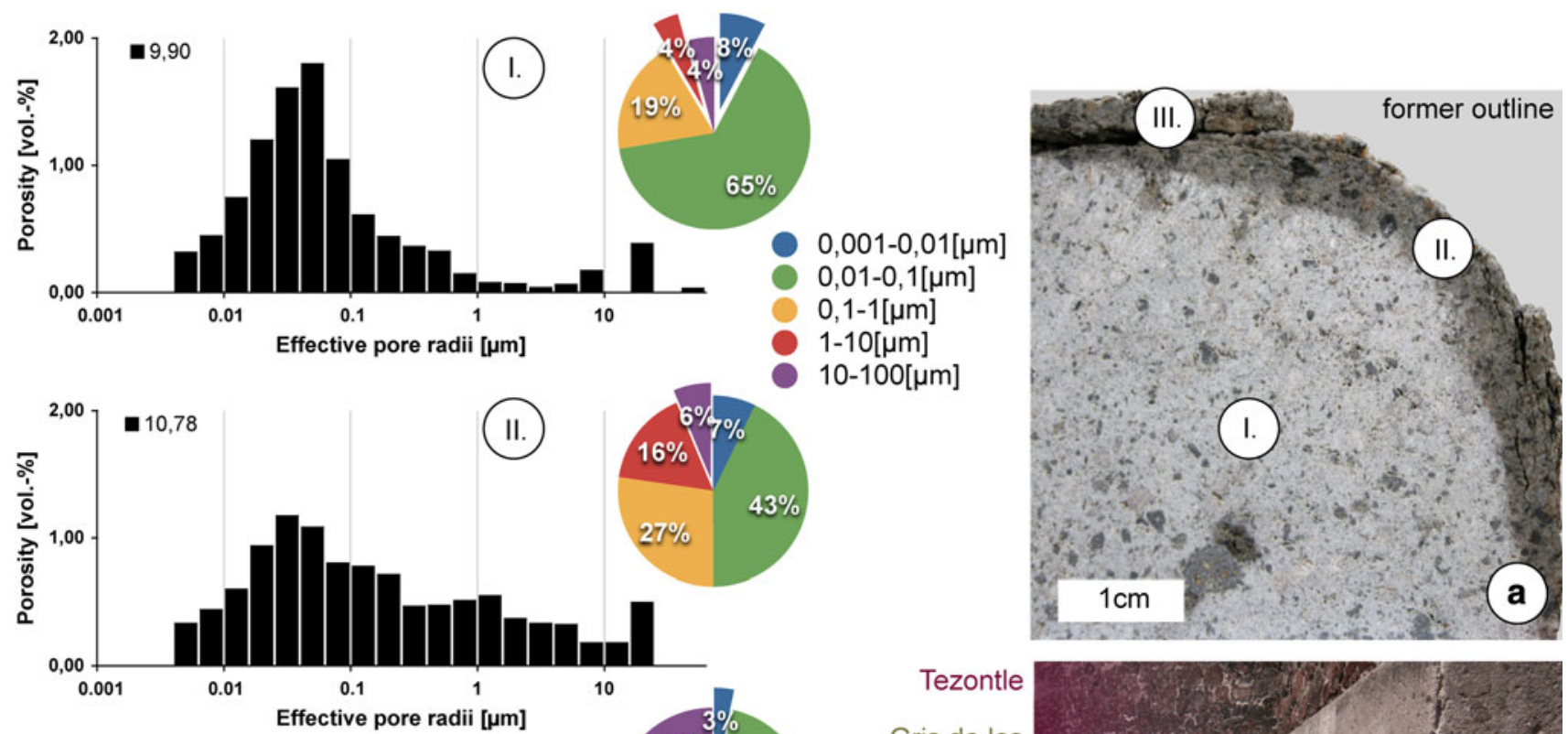

$0-100[\mu \mathrm{m}]$
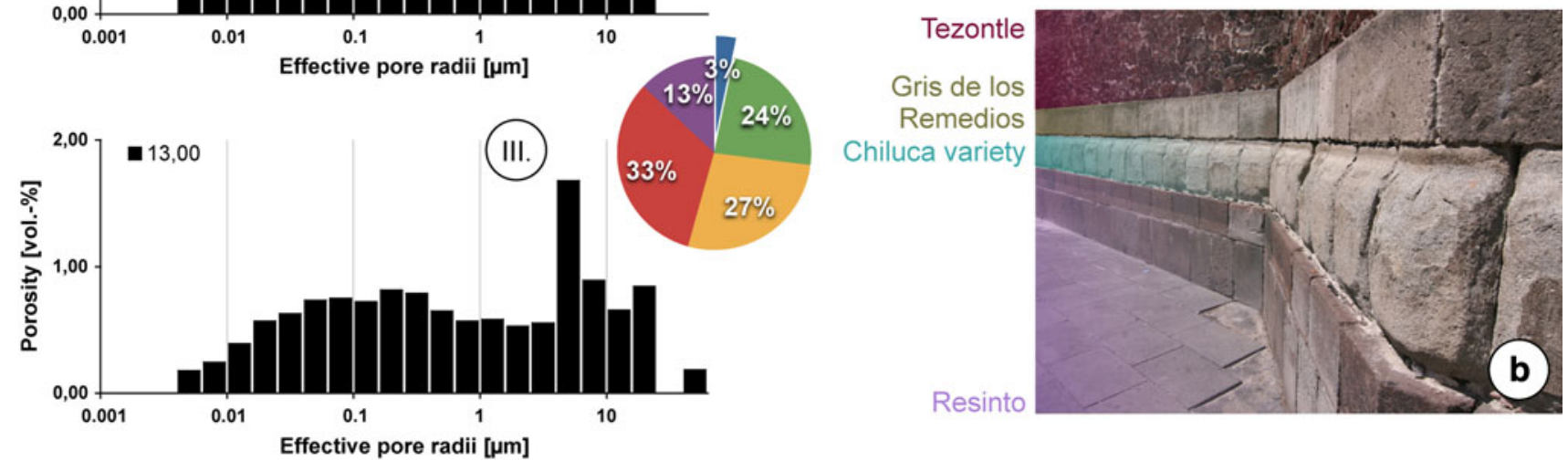

Fig. 5 a Truncated stone sample of pyroxene andesite from the Metropolitan Cathedral. I, II and III depict changing pore radii distributions according to the different zones of weathering. b Rounding in the Chiluca variety

\section{Tenayocátetl rhyolitic ignimbrite}

The volcanic rock from tenayocátetl (II) is grayish to red in color and is characterized by a porhyritic fabric. By mineralogical classification, the rock exhibits a rhyolitic composition and represents a welded ash tuff with a small portion of lapilli fragments. This rock shows the characteristic foliation, which is caused by flow structures. Microscopically the fine-grained ash matrix cannot be further detected. The lapilli fragments mainly show rounded quartz.

Altered crystals of plagioclase, hornblende, andesine, oligoclase, labradorite and augite are observable. Within the fine matrix, small acicular crystals define the flow direction (Fig. 6, third row). This matrix is colored in layers from light red to dark red because of kaolinite and hematite.

Because of the limited amount of original historical material available, compressive strength tests could only be done in the fabric directions parallel $(Y)$ and perpendicular $(Z)$ to the flow direction under dry conditions.
Tenayocátetl has a porosity of $7.3 \%$ and a density of $2.45 \mathrm{~g} / \mathrm{cm}^{3}$ (Table 1) The $w$ value shows extreme anisotropic behavior of nearly $99 \%$. While the $w$ values in the $Z$ and $X$ direction only reach $0.10-0.11 \mathrm{~kg} \mathrm{~m}^{-2} \mathrm{~h}^{-1 / 2}$, the $Y$ direction with a value of $9.16 \mathrm{~kg} \mathrm{~m}^{-2} \mathrm{~h}^{-1 / 2}$ is nearly ten times higher. (Table 2). The pore radii distribution shows an amount of nearly $53 \%$ as sum of all fractions of capillary active pores $(0.1$ to $>10 \mu \mathrm{m})$ as well as a proportionate dominance of micropores $(0.01-0.1 \mu \mathrm{m})$ of nearly $38 \%$ (Table 1). Thermal dilatation reaches $9.71 \mathrm{~mm} / \mathrm{m}$ with a very low anisotropy of $2.2 \%$ (Table 3 ). Also for the rhyolitic Ignimbrite a residual strain after five heating-cycles could not be detected.

Hygric swelling shows an extreme anisotropic behavior of $51.4 \%$ : hygric swelling in the $Z$ direction with $5.68 \mathrm{~mm} /$ $\mathrm{m}$ reaches a value nearly two times higher than in the other fabric directions (Table 3).

Compressive strength attains a value of $50.83 \mathrm{~N} / \mathrm{mm}^{2}$ by isotropic behavior (Table 4). The e-module ranges from 12.13 to $14.81 \mathrm{kN} / \mathrm{mm}^{2}$ with a moderate anisotropic behavior of almost $17 \%$. 

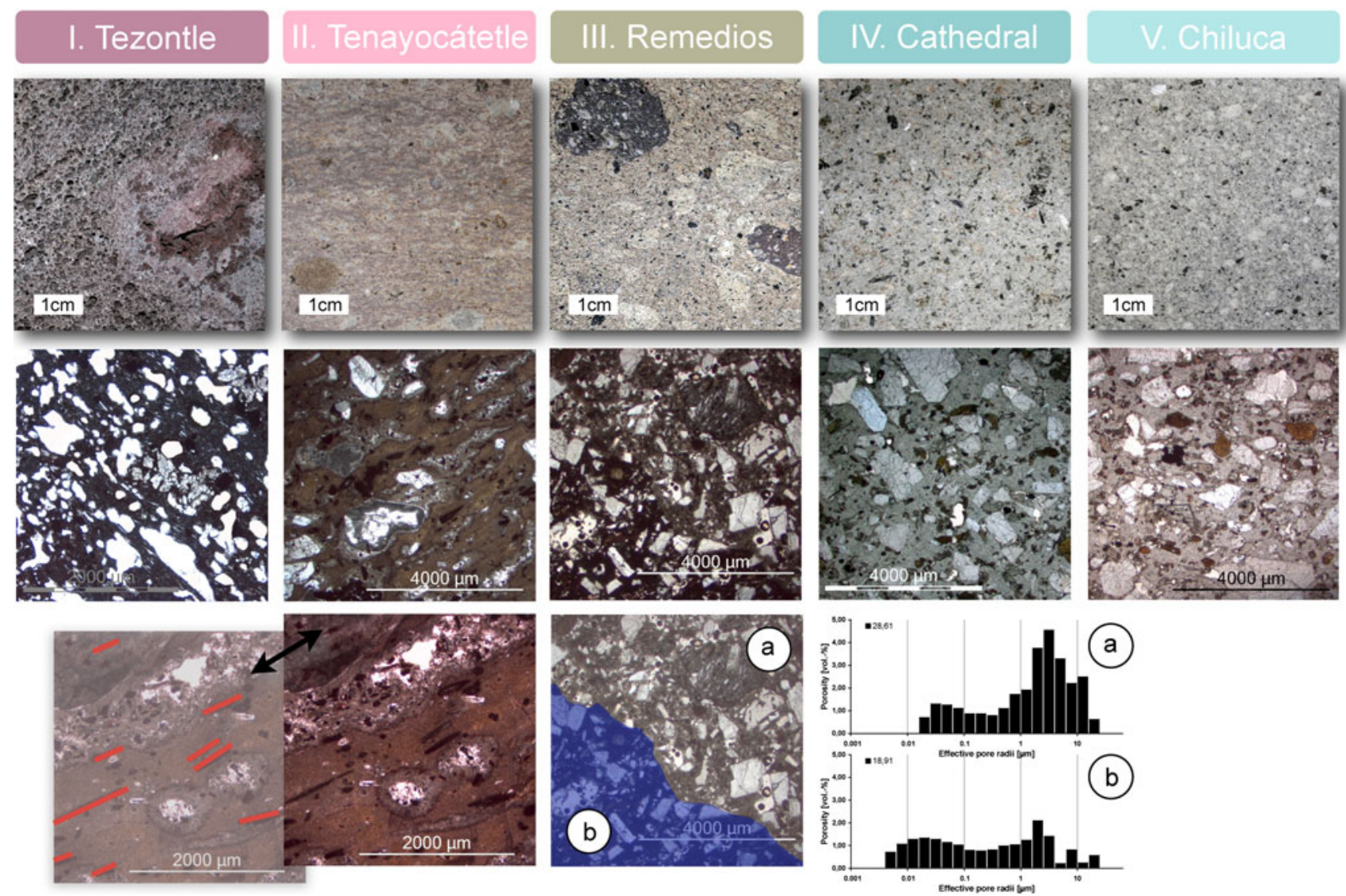

Fig. 6 First row the different building stones. Second row thin sections. Third row remarks ( $a$ matrix of the Remedios tuff and its pore size distribution, $b$ inclusion of the Remedios tuff and its pore size distribution)

Table 1 Pore space and density properties of the investigated rocks

\begin{tabular}{|c|c|c|c|c|c|c|c|c|c|}
\hline \multirow[t]{2}{*}{ Rock type } & \multirow{2}{*}{$\begin{array}{l}\text { Porosity } \\
\text { (Vol.\%) }\end{array}$} & \multirow{2}{*}{$\begin{array}{l}\text { Bulk density } \\
\left(\mathrm{g} \mathrm{cm}^{-3}\right)\end{array}$} & \multirow{2}{*}{$\begin{array}{l}\text { Particle density } \\
\left(\mathrm{g} \mathrm{cm}^{-3}\right)\end{array}$} & \multirow{2}{*}{$\begin{array}{l}\text { Average pore } \\
\text { radius }(\mu \mathrm{m})\end{array}$} & \multicolumn{5}{|c|}{ Pore radii distribution $(\%)$} \\
\hline & & & & & $0.001-0.01(\mu \mathrm{m})$ & $0.01-0.1(\mu \mathrm{m})$ & $0.1-1(\mu \mathrm{m})$ & $1-10(\mu \mathrm{m})$ & $>10(\mu \mathrm{m})$ \\
\hline Tezontle & 51.8 & 1.40 & 2.71 & 1.870 & 8.3 & 15 & 10 & 22.5 & 43.7 \\
\hline Cathedral & 10.6 & 2.40 & 2.68 & 0.114 & 5.9 & 56.3 & 23.8 & 2.9 & 10.9 \\
\hline Chiluca & 8 & 2.37 & 2.58 & 0.358 & 4 & 22.8 & 40 & 30 & 3.2 \\
\hline Tenayocátetl & 7.3 & 2.27 & 2.45 & 0.303 & 9.2 & 37.8 & 15.8 & 19.6 & 17.5 \\
\hline Remedios & 28.2 & 1.82 & 2.55 & 1.285 & 0 & 15.3 & 18.8 & 55 & 10.9 \\
\hline
\end{tabular}

Table 2 Moisture transport properties of the investigated rocks in non-weathered condition (anisotropy calculated with $A=n_{\max }-$ $\left.n_{\min } / n_{\max } \times 100\right)$

\begin{tabular}{lllll}
\hline Rock type & \multicolumn{2}{l}{$w$ value $\left(\mathrm{kg} \mathrm{m}^{-2} \mathrm{~h}^{-1 / 2}\right)$} & $A(\%)$ \\
\cline { 2 - 4 } & $X$ & $Y$ & $Z$ & \\
\hline Tezontle & 0.39 & 0.45 & 0.38 & 15.5 \\
Tenayocátetl & 0.11 & 9.16 & 0.10 & 98.9 \\
Remedios & 8.30 & 9.08 & 6.21 & 30.8 \\
Cathedral & 0.30 & 0.37 & 0.32 & 18.9 \\
Chiluca & 0.39 & 0.34 & 0.38 & 12.8 \\
\hline
\end{tabular}

While the stone shows nearly the same values according to its mechanical properties, the water uptake capacity and the hygric dilatation show extreme anisotropic values (Tables 2, 3). Water suction only seems to be possible through the direction of lineation $(Y)$. Hygric expansion shows an anisotropic value of $51.4 \%$. The expansion perpendicular to the flow direction is almost two times higher than parallel to the direction of foliation or lineation.

The thermal expansion shows height values and isotropic behavior (Table 3). Thermal expansion is reaching $5.6 \mathrm{~mm} / \mathrm{m}$ at $60^{\circ} \mathrm{C}$ and $9.8 \mathrm{~mm} / \mathrm{m}$ at $90^{\circ} \mathrm{C}$. 
Table 3 Thermal expansion coefficients $(\alpha)$ and the residual strain of one heating cycle $\left(20-90-20{ }^{\circ} \mathrm{C}\right)$ as well as the hygric expansion of the investigated rocks in non-weathered condition

\begin{tabular}{|c|c|c|c|c|c|c|c|c|}
\hline \multirow[t]{2}{*}{ Rock type } & \multicolumn{4}{|c|}{ Thermal dilatation } & \multicolumn{4}{|c|}{ Hygric expansion } \\
\hline & $X\left(\mathrm{~mm} \mathrm{~m}^{-1}\right)$ & $Y\left(\mathrm{~mm} \mathrm{~m}^{-1}\right)$ & $Z\left(\mathrm{~mm} \mathrm{~m}^{-1}\right)$ & $A(\%)$ & $X\left(\mathrm{~mm} \mathrm{~m}^{-1}\right)$ & $Y\left(\mathrm{~mm} \mathrm{~m}^{-1}\right)$ & $Z\left(\mathrm{~mm} \mathrm{~m}^{-1}\right)$ & $A(\%)$ \\
\hline Tezontle & 7.01 & 6.97 & 7.52 & 7.3 & n.d. & n.d. & n.d. & - \\
\hline Cathedral & 7.91 & 7.78 & 7.50 & 5.1 & 3.05 & 2.98 & 3.05 & 2.3 \\
\hline Chiluca & 7.80 & 8.42 & 6.85 & 18.6 & 2.82 & 2.81 & 3.02 & 6.9 \\
\hline Tenayocátetl & 9.71 & 9.60 & 9.82 & 2.2 & 2.76 & 3.14 & 5.68 & 51,4 \\
\hline Remedios & 6.7 & 5.7 & 6.03 & 14.9 & 4.94 & 5.88 & 6.21 & 20,4 \\
\hline
\end{tabular}

Anisotropy calculated with $A=n_{\max }-n_{\min } / n_{\max } \times 100$

n.d. not detectable

Table 4 Compressive strength in dry and water-saturated conditions as well as the elastic modulus

\begin{tabular}{llllllr}
\hline Rock type & $\begin{array}{l}\text { Direction/ } \\
\text { anisotropy }\end{array}$ & Tezontle & Cathedral & Chiluca & Tenayocátetl & Remedios \\
\hline $\begin{array}{c}\text { Compressive strength dry } \\
\left(\mathrm{N} / \mathrm{mm}^{2}\right)\end{array}$ & $X$ & 23.40 & 105.02 & 91.94 & 50.82 & 17.25 \\
& $Y$ & 21.33 & 97.78 & 83.2 & 50.86 & 16.58 \\
& $Z$ & 26.90 & 91.88 & 90.58 & 50.82 & 18.08 \\
& $A(\%)$ & 20.7 & 12.5 & 20.7 & 0.07 & 8.29 \\
Compressive strength water & $X$ & 23.67 & - & 76.45 & - & 10.03 \\
saturated (N/mm $\left.{ }^{2}\right)$ & $Y$ & 22.31 & - & 68.73 & - & 9.67 \\
& $Z$ & 27.76 & - & 71.29 & - & 10.82 \\
& $A(\%)$ & 19.6 & - & 10.0 & - & 10.62 \\
Compressive strength & & +3.01 & - & -19.6 & - & -41.2 \\
reduction $(\%)$ & $X$ & 5.8 & 9.8 & 12.70 & 14.81 & 3.14 \\
Young's modulus & $Y$ & 6.1 & 8.45 & 14.26 & 13.42 & 2.85 \\
$\left(\mathrm{kN} / \mathrm{mm}^{2}\right)$ & $Z$ & 5.3 & 10.2 & 14.12 & 12.13 & 3.85 \\
& $A(\%)$ & 13.1 & 17.1 & 10.9 & 16.8 & 26 \\
\hline
\end{tabular}

Remedios tuff (Gris de los Remedios)

The volcanic rock of Remedios represents a lapilli tuff (III), supported by an ash matrix. The color of this tuff is gray to light gray. Two types of lapilli fragments are distinguished, one is white in color, and the other is dark. The ash matrix is more or less gray. Within the matrix, dark spots occur that can be traced back to mafic minerals. The mafic minerals often show prismatic crystal shapes and represent mostly idiomorphic developed hornblende crystals. The white lapilli fragments are dominated by pumice.

Microscopic examinations revealed the presence of minerals and compounds like cristobalite, clays, sodium plagioclase, hornblende, and sparitic particles. While the crystals within the inclusions are unaltered, the crystals within the matrix show alteration. Both the matrix and the inclusions are closely connected. Between these two components, no pore space is observable (Fig. 6III). The porosity and density of the matrix and the inclusions differ at around $45 \%$. The pore radii distribution also differs in the same dimension (Fig. 6, third row). The matrix (a) shows a distinct concentration of capillary active pores (1-10 $\mu \mathrm{m})$, while the inclusions (b) show nearly the same volume of capillary active macropores and micropores $(0.001-0.1 \mu \mathrm{m})$. The inclusions define a flow orientation, whereas an orientation of the single crystals within the matrix cannot be discerned.

Secondary precipitated calcite is located in small cracks and in the pore space. Chemical analyses indicate that the calcite comprises $0.8 \mathrm{wt} \%$.

The porosity of Gris de los Remedios ranges from 24.5 to $31.5 \%$, whereas their bulk density is around $1.78-1.92 \mathrm{~g} /$ $\mathrm{cm}^{3}$. The average $w$ value reaches $7.8 \mathrm{~kg} \mathrm{~m}^{-2} \mathrm{~h}^{-1 / 2}$ with an anisotropy value of $30.8 \%$ (Table 2). The amount of capillary active pores comprises $84.7 \%$. From the capillary active pores, a $55 \%$ fraction ranges between 1 and $10 \mu \mathrm{m}$ (Table 1). Thermal dilatation averaged reaches $6.14 \mathrm{~mm} / \mathrm{m}$ with a moderate anisotropy of nearly $15 \%$ (Table 3 ). A low 
residual (irreversible) strain during the five cycles of measurement could be detected.

Hygric swelling averages show a value of $5.67 \mathrm{~mm} / \mathrm{m}$ with an anisotropy of $20.4 \%$ (Table 3 ).

Under dry conditions, the compressive strength of single samples ranges from 15.8 to $19.3 \mathrm{~N} / \mathrm{mm}^{2}$. The anisotropy amounts to $8.29 \%$ (Table 4). The elastic modulus ranges from 3 to $5 \mathrm{kN} / \mathrm{mm}^{2}$ with an anisotropic behavior of around $26 \%$. The Remedios variety has an average compressive strength of $17.3 \mathrm{~N} / \mathrm{mm}^{2}$ and an e-module of $8.29 \mathrm{kN} / \mathrm{mm}^{2}$.

At water saturation, the compressive strength decreases down to $10.17 \mathrm{~N} / \mathrm{mm}^{2}$ by a moderate anisotropy of $10.6 \%$ (Table 4). Compressive strength decreases to $41.2 \%$ according to the measurements under dry conditions (Table 4).

The stone has a high $w$ value $\left(7.8 \mathrm{~kg} / \mathrm{m}^{2}\right)$ and a high hygric dilatation by reaching an average value of $5.6 \mathrm{~mm} /$ $\mathrm{m}$. Both values clearly show anisotropy. The w-value is nearly $31 \%$ and the hygric dilatation $20 \%$ (Tables 2, 3). Average compressive strength values only reach $17.3 \mathrm{~N} /$ $\mathrm{mm}^{2}$ at dry conditions and decreases to $10.1 \mathrm{~N} / \mathrm{mm}^{2}$ in the water-saturated state, a reduction of $41 \%$ according to the measurements under dry conditions (Table 4).

The thermal dilatation also reaches critical values of around $4 \mathrm{~mm} / \mathrm{m}$ at $60^{\circ} \mathrm{C}$ and around $6 \mathrm{~mm} / \mathrm{m}$ at $90^{\circ} \mathrm{C}$. The curve does not follow a linear gradient. When heating up to $60^{\circ} \mathrm{C}$, a small depression is recognized. This reduction is probably caused by the dehydration of crystal water within the material. After five cycles, a residual strain could not be detected.

The investigated material was coming from the quarries of Los Remedios located in the mountains northwest of Mexico City.

\section{Chiluca: fresh and altered (Cathedral)}

Two varieties of the pyroxene andesite tuff Chiluca have been investigated, an altered sample from the cathedral (described as Cathedral, IV), and a fresh sample from a quarry (described as Chiluca, V). The altered Chiluca tuff sample was removed from the cathedral during the current restoration campaign. The properties of the Chiluca type of the Cathedral differ from the fresh sample.

The Chiluca tuff represents an ash tuff with a high proportion of fragmented feldspar single crystals, giving the rock a porphyritic appearance. The tuff is gray in color with dark inclusions of mafic minerals, which is probably amphibole. Feldspar single crystals occur in a fine-grained matrix. Microscopic examinations show that both stone varieties have a vesicular phenoporphyritic texture and microcrystalline matrix consisting of andesite constituents (around 85\%). In both varieties, hornblende crystals are present (around 15\%) (Martínez and Martínez 1991).

Some crystals show alteration (Fig. 6, second line) in the sample from the cathedral, whereas the crystals within the matrix of the new stone from the chiluca quarry mostly are still intact (Fig. 6, second line). The Chiluca variety also shows isolated augite crystals and plagioclase. An orientation within the fine matrix cannot be discerned by standard microscopic techniques. Macroscopic observations detected an orientation in the elongated hornblende crystals.

The porosity measured in the altered cathedral variety is $10.6 \%$ with the density being $2.68 \mathrm{~g} / \mathrm{cm}^{3}$ (Table 1 ). The Chiluca variety comes with a porosity of $8 \%$ and a density of $2.58 \mathrm{~g} / \mathrm{cm}^{3}$ (Table 1). Both varieties differ in porosity and density by only $2 \%$. The $w$ value of the cathedral variety averaged $0.33 \mathrm{~kg} \mathrm{~m}^{-2} \mathrm{~h}^{-1 / 2}$ with an anisotropy of nearly $19 \%$, whereas the Chiluca variety shows a $w$ value of $0.37 \mathrm{~kg} \mathrm{~m}^{-2} \mathrm{~h}^{-1 / 2}$ with a moderate anisotropy of around $13 \%$ (Table 2). Active capillary pores in the case of the altered cathedral variety reach $37.6 \%$ and in the sample from Chiluca $73.2 \%$ (Table 1). The highest amount of pore fractions $(56.3 \%)$ within the pore radii distribution in the cathedral variety can be found for micropores with a pore radii size of $0.01-0.1 \mu \mathrm{m}$, whereas the Chiluca variety has a concentration of $40 \%$ for the pore radii fraction ranging from 0.1 to $1 \mu \mathrm{m}$ (Table 1). Thermal dilatation of the altered variety averaged around $7.73 \mathrm{~mm} / \mathrm{m}$ with a low anisotropy of $7.3 \%$ (Table 3). Only for the samples from the cathedral, a low residual strain could be detected.

Hygric swelling shows a value of $3.02 \mathrm{~mm} / \mathrm{m}$ with a very low anisotropy of only $2.3 \%$ (Table 3 ). In the quarry fresh Chiluca, the value of thermal dilatation averaged $7.69 \mathrm{~mm} / \mathrm{m}$ and is comparable to the altered stone, but it has a clear anisotropy of around 19\% (Table 3). Hygric swelling reaches an average of $3.1 \mathrm{~mm} / \mathrm{m}$ and is slightly higher than the sample from the cathedral as well as showing an anisotropy of nearly $7 \%$ (Table 3 ).

Both varieties have a high compressive strength. The altered variety averaged $98.2 \mathrm{~N} / \mathrm{mm}^{2}$ with an anisotropy of $12.5 \%$, whereas the Chiluca variety shows a value of $88.6 \mathrm{~N} / \mathrm{mm}^{2}$ with an anisotropy of $21 \%$ (Table 4 ).

The modulus of elasticity of the cathedral variety ranges from 8.45 to $10.2 \mathrm{kN} / \mathrm{mm}^{2}$ with an anisotropic behavior of around $17 \%$, whereas the Chiluca only shows an anisotropy of $11 \%$ and a averaged e-module of $13.7 \mathrm{kN} / \mathrm{mm}^{2}$. Because of the limited amount of the original historical material, compressive strength by water saturation could only be measured for the fresh Chiluca variety. By compressive strength tests at water saturation, a decrease of nearly $20 \%$ took place in the this variety (Table 4). 


\section{Discussion}

All five building stones show different petrophysical properties and specific weathering and deterioration forms under the same environmental conditions. Whereas tezontle and Gris de los Remedios in historical buildings show a significant resistance towards weathering, the andesite varieties are more vulnerable for different weathering phenomenon. In field studies the building structure and position of the different building stones within the construction was also regarded:

\section{Sample I}

I. The main building material in Aztec times, Tezontle, could be easily mined by fracturing because of the moderate hardness with a compressive strength average of $23.8 \mathrm{~N} / \mathrm{mm}^{2}$. The scoria mainly is out of glass making the material highly fragile. The low specific density also allowed the stone to be transported by boats (Table 1). The material was mostly used as rubblestone. Big building blocks were an exception. Therefore, tezontle could not be used for larger self-supporting structures. The moderate hardness and its premature fracture formation during the lava cooling process seems to be the reason why the material is so susceptible to crack formation. Tezontle nearly shows no hygric swelling and a low $w$ value (Table 2) by a moderate compressive strength and a low Young's modulus (Table 4). These properties, on the other hand, are ideal for compact structures on muddy ground. The specific material properties seem to be the one contributing factor for the formation of the typical compact outline discernible in Aztec architecture.

Water uptake only takes place in the compact mostly reddish colored areas of the material. Only these areas come with a capillary active porosity. These linked pore space areas are sporadic within the material. Therefore, tezontle does not show any susceptibility neither for rising damp nor capillary action. Tezontle nearly shows no hygric swelling but a high thermal dilatation (Table 3).

In tezontle, crack formation is also detectable because of the improper masonry mortar (Fig. 2a, Sagarra Lagunes 1993), where the Young's modulus is potentially to high according to the moderate values for tezontle of $5.73 \mathrm{kN} /$ $\mathrm{mm}^{2}$ (Table 4).

Natural building stones were selected in colonial times not only because of their use for decoration but also for building construction purposes. This systematic construction also exemplifies the mapping of the pedestal area as well as the first floor of the palace of Heras Soto (Fig. 3c, d).

Basalts like recinto with a low capacity for water uptake and a high resistance towards hygric swelling, were mostly used for the basement area followed by an array of an andesitic variety (Figs. 3c, 5b). To this day the different basaltic varieties show almost no weathering.

\section{Sample II}

While the tenayocátetl variety shows nearly the same values according to its mechanical properties, the water uptake capacity and the hygric dilatation show extreme anisotropic values (Tables 2,3). Water suction seems to be possible only more or less through the fluidal direction of the material $(Z)$. Hygric expansion also shows extreme anisotropic values: The expansion perpendicular to the flow direction is almost two times higher than parallel to the direction of foliation or lineation. Thermal expansion shows high values but nearly isotropic behavior (Table 3) by reaching a value of $5.6 \mathrm{~mm} /$ $\mathrm{m}$ at $60^{\circ} \mathrm{C}$ and $9.8 \mathrm{~mm} / \mathrm{m}$ at $90^{\circ} \mathrm{C}$.

The anisotropic properties in the tenayocátetl variety with respect to the $w$ value and the hygric expansion are responsible for the described weathering forms. Water transport, swelling and shrinking pressure and salt seems to be responsible for the deterioration. Scaling of the platform plates of the Templo Mayor can also be increased because of the hydrophobizing in the 1980s (Wacker and Meyer 1997).

\section{Sample III}

In the tuff variety Gris de los Remedios, one reason for its general resistance could be found in the bond of the matrix and the inclusions. The both component are closely connected. This bonding seems to be one reason, why we find no back-weathering of clastic material. Normally the clastic material weathers out. This is an often recognized phenomenon of many rhyolitic tuffs (Török et al. 2005) and is also found in different tuff varieties of México like for example in Guadalajara (Jáuregui and Wedekind 2009). Compositionally the stone is classified as an andesitic or trachytic-andesitic tuff (Ordónez and Ezequiel 1996). The tuff is showing a low residual strain, but hair cracks or craquele, which are often found in sun-exposed surfaces of different Mexican tuff varieties, could not be observed.

The field observations and the results of the investigations lead to the conclusion that hygric expansion probably in combination with the action of salt weathering is the main factor for the weathering of the tuff variety Gris de los Remedios. Salt efflorescences can be often recognized in combination with weathering phenomena and are an indicator for wet-dry conditions. This hypothesis is confirmed by the use of the tuff variety as a part of the architectural structure: The Remedios tuff was mainly used for architectural sculptures in areas that are not directly affected by water. In the tuff that was used in the palace Heras Soto for the ground floor weathering can be 
recognized. This part of the building is affected by wet-dry conditions (Fig. 3c).

\section{Sample IV, V}

New mining methods at the beginning of industrialization (late eighteenth century) created means for excavating large amounts of the phenoporphyritic andesite for the cathedrals main facade and bell towers. Before this tine these types of andesites were normally used for the construction of the ground floor and pedestal areas. Both building parts, the bell towers as well the foundation zones are affected by wet-dry conditions. In the phenoporphyritic andesite the limited depth of weathering seems to be connected to the low w-value measured in both varieties (Table 2). Chiluca contains a low porosity; the w-value is a littler higher than the original material of the cathedral (Table 2). This is due to the different pore radii distributions in both varieties. The active capillary pore space of Chiluca accounts for $73.2 \%$, whereas the original material of the cathedral only attains a value of $37.6 \%$ (Table 1). During a water uptake of $4 \mathrm{~h}$, suction of only $0.5 \mathrm{~cm}$ could be determined. This correlates with the depth profile of weathering and crust formation (Fig. 5).

The concentration of weathering in the outline of the stone can be traced back to the high hygric dilatation of the material and associated shear forces. During this process, insulation weathering also seems to play a role because of the thermal dilatation.

The pyroxene andesitic tuff of the cathedral shows a critical thermal expansion of around $4 \mathrm{~mm} / \mathrm{m}$ by heating up to $60^{\circ} \mathrm{C}$ and reaching nearly $8 \mathrm{~mm} / \mathrm{m}$ at $90^{\circ} \mathrm{C}$. The Chiluca stone shows similar values. A tendency of anisotropy to the fabric direction of foliation $(Z)$ can be detected. By heating up to $68^{\circ} \mathrm{C}$ a dint can be recognized during the linear gradient. This reduction is probably caused by the dehydration of crystal water within the material. Thermal expansion by heating up to $60^{\circ} \mathrm{C}$ is reached at around $4.2 \mathrm{~mm} / \mathrm{m}$ in the fabric directions $Z$ and $X$ and $5.3 \mathrm{~mm} / \mathrm{m}$ in the $Y$ direction. A similar anisotropic behavior occurs when the material is heated up to $90^{\circ} \mathrm{C}$ (Table 3).

These two critical property values, the high thermal dilatation and the high hygric swelling associated with shear and tension stress can give an explanation for weathering forms like scaling and rounding. For the variety of the Cathedral a low residual strain could be detected. Today Chiluca is used as a restoration material for the replacement of ashlars affected by weathering at the cathedral and other historical buildings. In comparison with the original stone of the cathedral, the investigated Chiluca samples show adverse properties towards weathering, especially when considering its higher water uptake capacity and lower compressive strength.

\section{Conclusion and prospects}

The results show that typical weathering forms can be deduced because of specific petrophysical properties on different rock materials. Significant anisotropic behavior or single critical values can influence the sensitivity to different weathering forms. With regard to the investigated rocks in this study, a factor that influences the creation of material immanent weathering starts with an anisotropy up to $20 \%$. Cementation can also play a key role in the rock's resistance to weathering.

The results help in the understanding of the different weathering processes, and contribute to the evaluation of the relevant different deterioration factors. In Mexico today, deteriorated stone material is usually replaced with a new one. The present investigation has shown that weathering is mostly limited to the surface area of the different materials. Conservation and preservation of the original historical material seems to be possible and more costeffective. Long-term studies and cost calculations have shown that conservation can be up to four times more costeffective than changing the stone material (Gräf 2009). Studies on consolidation were already done for three of the samples presented in this paper. These studies have shown best results for vinyl acetate, type Mowolith 50 and a silica acid ester, type Wacker OH (Martínez 1992).

Considering all available data for the rock types and conservation status of the described monuments, first steps in the development of a sustainable conservation procedure are already done. Future tasks have to be focused on the development of adequate methods and materials, like mortars for restoration.

Acknowledgments We would like to thank Dr. Axel Vollbrecht of the Geoscience Center of Göttingen, Mária Barajas Roche, Department Chairperson of Restoration at the Museo Templo Mayor, the architects and conservators of the Cathedral Metropolitan, INHA (Instituto Nacional de Antropologia e Historia), CONACULTA (Consejo Nacional para la Cultura y las Artes), Ing. Ricardo Luna Alvarado and the restorer conservator Karla Jáuregui Arreola. Our work was kindly supported by the Hans-Böckler-Fundation.

Open Access This article is distributed under the terms of the Creative Commons Attribution Noncommercial License which permits any noncommercial use, distribution, and reproduction in any medium, provided the original author(s) and source are credited.

\section{References}

Acevedo-Dávila LM, Torres-Treviño, Lauren YGZ (2007) Tezontle aggregate substitute optimization in building blocks mixture. Electronics, Robotics and Automotive Mechanics Conference (CERMA), Cuernavaca, pp 307-311

Brakel J, van Modry S, Svata M (1981) Mercury porosimetry: state of the art. Powder Technol 29:1-12 
Demm E (1991) Kolonialpaläste in Mexiko. Cologne: 83-94

Franco ML (1987) Conservation at the Templo Mayor of Tenochtitlán. In: Hodges Henry WM (ed) In situ archaeolocical conservation: Proceedings of meetings, April 6-13, 1986, Mexico. INAH, Mexico, pp 166-175

Gräf U (2009) Tauschen oder konservieren? Stein J Nat Stone 2009:30-33

Hassig R (1994) Mexico and the Spanish Conquest. Longman, New York

Jáuregui K, Wedekind W (2009) Die Restaurierung von Santa Mónìca in Guadalajara-Ein Pilotprojekt zur Etablierung neuer Standards und Methoden in der praktischen Denkmalpflege in Mexiko. In: Peltz U, Zorn O (eds) Kultur GuterhaltenStandards in der Restaurierungswissenschaft und Denkmalpflege. Berlin, pp 227-234

López Luján L, Torres J, Montúfar A (2003) Los Materiales constructivos del templo Mayor de Tenochtitlan. Estudios de Cultura Náhuatle 34:137-167

Martínez GM (1992) Aspectos fisicoquimicos del deterioro y conservacion de monumentos historicos de piedra. Tesis para la obtencion del grado de doctor en ciencias, Universidad Autonoma Metropolitana-Iztapalapa, Iztapalapa

Martínez GM, Martínez EN (1991) Characterization of stone from the Metropolitan Cathedral and from the facade of the National Museum at Tepotzotlan, Mexico. Stud Conserv 36(2):99-110

Neiderberger C (1996) The Basin of Mexico: a multimillennial development toward cultural complexity. In: Benson EP, de la Fuente B (eds) Olmec Art of Ancient Mexico. Washington, pp 83-93

Niederberger C (1979) Early sedentary economy in the Basin of Mexico. Science 203:131-142

Ordónez, Ezequiel (1996) Análisis químico de la Chiluca y de la Cantera-Vida y obra, Obra científica IV (1889-1898), México, El Colegio Nacional, pp 97-98

Ortiz Lajous J (1980) La restauración de la catedral y sagrario metropolitanos en la ciudad de México. Restauro: quaderni die restauro dei monumenti e di urbanistica dei centri antichi $51: 3-59$
Parker G (1995) The Times - Große illustrierte Weltgeschichte. Vienna p 268

Pirella Meli R, Ramírez Sánchez A (2001) La rehabilitación de la catedral Metropolitana de la Ciudad de México. Revista Digital Universitaria, 30 June 2001, 2(2) www.revista.unam.mx/vol.2/ num $2 /$ proyec $1 /$ index.html

Ruedrich J, Kirchner D, Seidel M, Siegesmund S (2005) Beanspruchungen von Naturwerksteinen durch Salz- und Eiskristallisation im Porenraum sowie hygrische Dehnungsvorgänge. In: Siegesmund S, Auras M, Ruedrich J, Snethlage R (eds) Geowissenschaften und Denkmalpflege.-Z. dt. Geol. Ges. 156(1):59-73

Sagarra Lagunes MM (1993) La conservation de la pierre dite "tezontle" au Mexique. In: Thiel MJ, Conservation of stone and other material. vol 1, London, pp 411-416

Sanders WT (2008) Tenochtitlan in 1519: a pre-industrial megapolis. In: Brumfield EM, Geinmann GM (eds) The Aztec World. New York pp 66-85

Suárez Pareyón Aveleyra L (2002) Composición y alteración de la toba volcánica de la fachada de un edificio en el centro histórico de la ciudad de México. In: Vontobel R (eds) 13th triennial meeting, Rio de Janeiro, 22-27 September 2002 London pp 816-819

Tamez E, Santoyo E, Ovando E (1997) Aspectos geotécnicos de la corrección geométrica de las cimentaciones de Catedral y Sagrario. In: Fernández M (ed) La catedral de Méxicoproblemática, restauración y conservación en el futuro. 2. Coloquio del seminario de estudio del patrimonio artístico, México, pp 119-149

Török Á, Vogt T, Löbens S, Forgó LZ, Siegesmund S, Weiss T (2005) Weathering forms of rhyolite tuffs. Zeitschrift der Deutschen Gesellschaft für Geowissenschaften. ZDGG 156(1):177-187

Wacker D, Meyer O (1997) Die Kunst zu bewahren. Munich

Weiss T, Siegesmund S, Kirchner D, Sippel J (2004) Insolation weathering and hygric dilatation: two competitive factors in stone degradation. Env Geol 46:402-413 